Editorial

\title{
Uma música, uma ficção e a ação
}

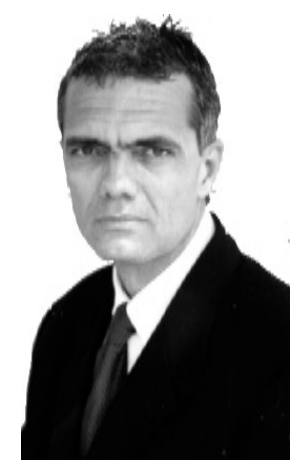

Marco Antonio Guimarães da Silva,Med.Dr.Sci.

marco@atlanticaedu.com.br

Há um tema filosófico - iniciado por Rousseau e muito discutido pelos filósofos dos séculos XIX e XX - que pergunta se a cultura é inimiga da vida. A questão acaba parando no pensamento do pai da psicanálise, o qual retoma a interessante oposição entre a biologia e a cultura. Para Freud, o homem aspira à felicidade, obviamente buscando o prazer e fugindo da dor. Na tentativa de fugir dessa dor e alcançar a almejada felicidade, esse homem lança mãos de zilhares de estratégias. Isso explica o sucesso e a fortuna de alguns escritores especializados em confortar e iludir, sem preocupação com o rigor ou a criação literária, as pobres almas humanas ávidas pela tal felicidade. Tal fato igualmente justifica o espaço tomado pelas propostas religiosas e evangélicas, que, de forma semelhante aos tais escritores oportunistas de plantão, faturam como nunca nos nossos e em outros distantes rincôes. O refúgio em um mecanismo psicológico de sublimação dos instintos parece encobrir momentaneamente o problema.

Procurando refletir sobre a infelicidade humana, o mesmo Freud define, em um primeiro momento, três fontes para as suas causas: o poder da natureza; a decadência de nosso próprio corpo e insuficiência de nossos métodos para regular as relaçóes humanas na família, no estado e na sociedade. Mas o psicanalista acaba por observar que a principal causa da nossa infelicidade e dor não são os fatores naturais nem os fatores externos, e sim aqueles que dependem do tipo de sociedade e cultura que nós mesmos construímos. E aí, seguindo a teoria freudiana, vamos chegar à repressão dos instintos (e tal e coisa), considerados forças antagônicas ao homem, o qual, muitas vezes, biologicamente, deseja a desordem; enquanto os valores que estabelecemos na nossa cultura impedem essa mesma desordem.

Os instintos de agressão e autodestruição, carros chefes da desordem, podem decidir a destruição dos valores culturais instituídos. Podem decidir ou já decidiram, caso levemos a sério o que os jornais estampam em seus noticiários, cujas reportagens são a expressão de uma sociopatia capaz de fazer inveja à sociedade das almas inquilinas das trevas. Ideologias, credos, classe e funções sociais encontram, nas noticias desses jornais, forças suficientes para estratificar a sociedade em que vivemos em ruim, numa visão muito otimista, ou muito ruim, numa visada mais realista

Enquanto esperamos o fim do fim, ao que tudo indica ingênua e resignadamente, e esquecemos, momentaneamente, as profecias apocalípticas desse editor, podemos lançar mão dos seguintes meios atenuadores:

Primeiro: ouvir a musica "Vilarejo", cuja letra e refrão transcrevo em parte abaixo, e imaginar-se transportado para o paraíso:

Há um vilarejo ali

Onde areja um vento bom

$\mathrm{Na}$ varanda, quem descansa

Về o horizonte deitar no chão

Pra acalmar o coração

Lá o mundo tem razão

Terra de heróis, lares de mãe

Paraiso se mudou para lá

Por cima das casas, cal

Frutos em qualquer quintal

Peitos fartos, filhos fortes

Sonho semeando o mundo real

Toda gente cabe lá

Palestina, Shangri-lá

...Lá o tempo espera

Lá é primavera

Portas e janelas ficam sempre abertas pra sorte entrar

E em todas as mesas: pão, flores enfeitando

Os caminhos, os vestidos, os destinos

E essa canção tem um verdadeiro amor

Para quando você for...

Marisa Monte, Pedro Baby, Carlinhos Brown e Arnaldo Antunes. 
Segundo: fingir-se turista em sua própria cidade. A gente acaba descobrindo que, quando somos turistas, em qualquer cidade do mundo, fora do Brasil é claro, não nos preocupamos com eleições de políticos corruptos, com máfias seja de onde for, com imundícies e sujeiras de bairro,apesar de sabermos que, também lá, esses problemas existem, em escala infinitamente menor. Não nos esqueçamos, inclusive, do direito de ir e vir, no ar ou na terra, sem correr risco de vida, o que, por aqui, parece que se tornou um luxo.

Talvez possamos acrescentar ainda uma opçáo: indignarmo-nos e agir, seja participando de passeatas, seja organizando abaixo assinados e, principalmente, votando com muito cuidado na próxima eleição (sem esquecer de rezar para que apareça alguém digno de receber os nossos votos, já que, na política esse espécime parece estar em extinção).

Espero que a primeira das sugestóes nos mostre que, pelo menos no plano imaginário, "o lugar" pode existir; que a segunda sugestão sirva apenas, no plano da meditação, para nos dar a isenção e o equilíbrio necessários a sábias decisóes; mas que a última das sugestóes possa se incorporar no cotidiano do nosso agir. 